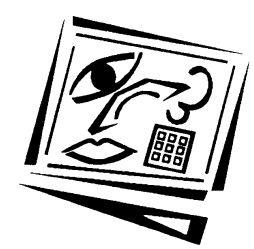

\title{
Developing leadership potential for technology integration: Perspectives of three beginning teachers
}

\author{
Ping Gao, Angela F. L. Wong, Doris Choy and Jing Wu \\ Nanyang Technological University
}

\begin{abstract}
This paper reports one major finding from a large two-year, mixed-methods study that investigated the process of beginning teachers' learning to teach with information and communication technology (ICT). Among the ten participants involved in the qualitative portion of the study, three stood out from the rest in their effort to use ICT in student-centred teaching approaches and translating their constructivist orientation learned from the university into classroom practice. They began to develop leadership potential to influence their university peers and their cooperating teachers during their ten-week period of student teaching (Gao, Choy, Wong \& Wu, 2009). During their first year of teaching, they continued to develop their leadership potential for technology integration by teaching with their 'technology savvy' strengths, leading their colleagues in school-wide technology initiatives, and supporting other beginning teachers. This study suggests that beginning teachers can learn to teach with ICT and lead in technology integration at the beginning stage of teacher development.
\end{abstract}

\section{Introduction}

Rapid technological advance has promoted social and educational changes. As new and emerging technologies offer competitive advantages to teaching, it is more critical than ever to prepare a new generation of technology capable teachers and leaders. The new generation - Gen Y, who were born between the early 1980s and the late 1990s tends to be more capable in engaging digital technologies and effecting positive change for the future (Donnison, 2005, 2007). Furthermore, according to Donnison (2009), Gen Y has other characteristics, like technological efficiency, confidence, optimism, enthusiasm, sociability, conservatism, idealism, an orientation towards success, tolerance, and social, environmental and community awareness (Donnison, 2005, 2007; Paul, 2001; Shepherdson, 2000).

With exposure to technology as students in the millennium era, most Gen $Y$ beginning teachers are more knowledgeable about ICT integration compared to their more experienced colleagues. They have been exposed to the first-hand learning experiences of new ideas and approaches about teaching and learning as students themselves. This unique phenomenon puts this generation of beginning teachers in a better position for both classroom teaching and collaboration in the teacher community. There is a promise that beginning teachers can lead technology integration. Previous studies showed that a small number of exemplary pre-service teachers (Gao, 2005) and first year teachers are able to integrate technology in diverse and flexible ways over time to create student-centred learning environments (Goos, 2005; Pierson \& Cozart , 2005; Russell, Bebell, O'Dwyer \& O'Connor, 2003). These empowering experiences have the 
potential for strengthening first year teachers' position and helping them to settle down in their career (Andersson, 2006; Clausen, 2007; McGee, 2000).

This paper reports one major finding from a two-year study on developing leadership potential for technology integration from the perspectives of three beginning teachers in Singapore. Ten beginning teachers participated in the qualitative portion of the study. Three out of the ten participants effectively developed and demonstrated their leadership potential in the pedagogical use of information technology for classroom teaching and learning. During their ten week student teaching, they were willing to take the risk of trying out different technology applications with the aim of increasing student learning and achievement. They also developed their leadership potential by inspiring and supporting their cooperating teachers and university peers. In their first year of teaching, they continued to develop it further. The development of their leadership potential is not an event, but a process in which they discovered, built on their 'tech-savvy' strengths, and negotiated their agency and power in multiple social contexts. By tracking the development of their teacher leadership, this paper aimed to answer the following questions:

1. What are their beliefs of technology integration?

2. Can they begin to develop leadership potential for technology integration?

3. Can they sustain and expend their leadership potential for technology integration?

\section{Literature review}

Two bodies of literature were reviewed: the notions of teacher leadership and empirical studies for preparing beginning teachers for the effective use of ICT to develop their leadership potential.

\section{Teacher leadership}

In the last two decades, teacher leadership has attracted great attention because individual teachers are the single largest factor that adds value to student learning (Darling-Hammond, 2000; Katzenmeyer \& Moller, 2001). Lieberman and Miller (2004) identified the three transformative shifts for teaching: from individualism to professional community, from teaching at the centre to learning at the centre, and from technical and managed work to inquiry and leadership. They argued that "central to this expended vision of teaching is the ideal that teachers are also leaders, educators who can make a difference in schools and schooling now and in the future" (p.11). They also suggested that learning to lead is social, collaborative and contextdependent, and teacher leaders learn most by actual practice and performance on the job.

There has been a proliferation of definitions for teacher leadership developed over time. For example, Wasley (1991; p.21) defined teacher leadership as a way of "influencing and engaging colleagues toward improved practice", and Howey (1988; p.28) defined teacher leaders as those who are "coalescing others to act when they otherwise might not have". After meta-analysing the last two decades of research studies in teacher leadership, York-Barr and Duke (2004; p.287) pointed out that typically, teacher leaders are those who have significant teaching experience, are considered to be excellent educators, and respected by their peers. Therefore, they described teacher leadership as "the process in which teachers, individually or 
collectively, influence their colleagues, principals, and other members of the school communities to improve teaching and learning practices with the aim of increased student learning and achievement".

Traditionally, teacher leaders refers to those who are appointed department chairs, team and grade leaders, curriculum committee chairs, and more. For example, Howey (1988; p.28) highlighted the importance of leadership entitlement by arguing that teachers must "assume leadership positions that will enable them to model methods of teaching, coach and mentor colleagues, study critically and thoughtfully various aspects of classroom life, develop curriculum and instructional materials, and strengthen relationships between the school and home".

Andrew and Schwab (1993) found that it is not until the third year that a beginning teacher begins to develop leadership qualities after mastering the basic teaching skills. However, Kouzes and Posner (1995; p.386) argued that leadership is not a result of seniority but "an observable, learnable set of practices". Thus, ordinary people with the desire to lead can develop their leadership abilities if opportunities are provided.

However, preparing pre-service teachers as teacher leaders can be challenging as it is beyond the current scope of most pre-service programs. For example, Goodlad (1990) and Cochran-Smith (1991) found that most pre-service programs have failed to emphasise preparing pre-service teachers as teacher leaders. This is because most preservice programs still pay much attention to helping pre-service teachers to gain knowledge and skills, and to change attitudes by primarily addressing the concerns about self, tasks, and students pertaining to survival at the novice stage (Fuller, 1969).

\section{Developing beginning teachers' leadership potential for technology integration}

ICT has been perceived as a change agent for the teaching process (Johnson, Schwab \& Foa, 1999). Hence the preparation of today's and tomorrow's teachers to use ICT has been emphasised in teacher education programs. Although pre-service teacher education does provide fundamental experience in the use of technology (Thompson, Schmidt \& Davis, 2003), most beginning teachers do not translate their high ICT skills and comfort level for using ICT into high levels of technology integration in daily classroom instruction (Andersson, 2006; Russell et al., 2003; Wright \& Wilson, 2005). Specifically, there was limited use of technology that promoted higher order thinking and cooperative learning (Bird \& Rosaen, 2005; Brown \& Warschauer, 2006; Kay \& Knaack, 2005; Wright \& Wilson, 2005). However, in a study about ten pre-service teachers' learning to teach with ICT across the last semesters of their teacher preparation program in the United States, Gao (2005) found that a handful of preservice teachers began to develop leadership potential for technology integration by inspiring and supporting their peers, cooperating teachers and other staff members in their placement schools.

Emerging findings from the research with first year teachers also suggested that some first year teachers are making significant attempts to integrate technology into their teaching, and gradually developing the "varied and strong repertoire of technology use" $^{\prime \prime}$ as required of beginning teachers (Pierson \& Cozart, 2005). For example, Goos (2005) found that the three first year teachers developed individual agency - to take control of one's behaviour - for creating opportunities for student-centred use of technology and their own identity as users of technology. Similarly, McGee (2000) 
found that one beginning teacher worked as a "reflective practitioner" in her teaching. She was strongly motivated and persevered to become an effective technology user in the classroom by exposing her students to researching and collaborating through the use of ICT.

The above studies suggest that whether beginning teachers learn to teach with ICT or not, it is situated in individual and social contexts. When beginning teachers are making significant attempts to integrate technology into their teaching, they can gradually develop the "varied and strong repertoire of technology use" as required of beginning teachers (Pierson \& Cozart, 2005), and they will be able to use technology in diverse and flexible ways over time (Goos, 2005; Russell et al., 2003). These empowering experiences have the potential of strengthening first year teachers' position and helping them to settle down in their career (Andersson, 2006; Clausen, 2007; McGee, 2000). Though it is yet to be proven whether beginning teachers can become catalysts for technology integration in the school context, as some researchers had implied, it is for sure that these beginning teachers are more knowledgeable about ICT as compared to their more experienced colleagues. This advantage puts them in a better position for classroom teaching and collaboration in the teaching community in the area of ICT integration.

\section{Methods}

This paper reports part of the qualitative findings of a two-year mixed methods study (June 2006-July 2008), which followed a cohort of pre-service teachers enrolled in the one-year Postgraduate Diploma in the Education (PGDE) (Primary) program at the National Institute of Education (NIE) in Singapore to their first year of teaching.

We adopted a mixed method to investigate this complex inquiry from different directions to ensure methodological triangulation (Denzin, 1984). The data collection over the course of two years is presented in Table 1.

Table 1: Data collection

\begin{tabular}{|c|c|c|c|c|c|}
\hline & $\begin{array}{l}\text { Survey } \\
\text { data }\end{array}$ & $\begin{array}{l}\text { Individual } \\
\text { interview }\end{array}$ & \begin{tabular}{|c|} 
Group \\
discussions
\end{tabular} & $\begin{array}{c}\text { Lesson } \\
\text { observations }\end{array}$ & Artifacts \\
\hline \multirow[t]{2}{*}{$\begin{array}{l}\text { Year } 1 \text { of } \\
\text { study } \\
\text { (July 06- } \\
\text { June 07) }\end{array}$} & $\begin{array}{l}\text { 1st survey (Aug 06): } \\
\text { Before ICT course }\end{array}$ & $\begin{array}{l}\text { 1st interview } \\
\text { (Sept 06) : } \\
\text { Beginning of ICT } \\
\text { course }\end{array}$ & $\begin{array}{l}\text { 1st } \\
\text { discussion } \\
\text { (Feb 07) }\end{array}$ & $\begin{array}{l}\text { Not } \\
\text { applicable }\end{array}$ & $\begin{array}{l}\text { The final project of } \\
\text { ICT course }\end{array}$ \\
\hline & \begin{tabular}{|l|} 
2nd survey (Oct 06): \\
After ICT course \\
3rd survey (May 07): \\
After the 10-week \\
student teaching \\
\end{tabular} & $\begin{array}{l}\text { 2nd interview } \\
\text { (May, 07): After } \\
\text { the 10-week } \\
\text { student teaching }\end{array}$ & $\begin{array}{l}\text { 2nd } \\
\text { discussion } \\
\text { (May 07) }\end{array}$ & $\begin{array}{l}13 \text { lesson } \\
\text { observations } \\
\text { for the seven } \\
\text { focus } \\
\text { participants }\end{array}$ & $\begin{array}{l}\text { Lesson plans, } \\
\text { reflection, samples } \\
\text { of students' work, } \\
\text { informal discussion }\end{array}$ \\
\hline \multirow[t]{2}{*}{$\begin{array}{l}\text { Year } 2 \text { of } \\
\text { study } \\
\text { (July 07- } \\
\text { July 08) }\end{array}$} & $\begin{array}{l}\text { 4th survey (Apr 08): } \\
\text { After the first year } \\
\text { of teaching }\end{array}$ & $\begin{array}{l}\text { 3rd interview } \\
\text { (Dec 07): After } \\
\text { half year of } \\
\text { teaching }\end{array}$ & & \multirow{2}{*}{$\begin{array}{l}56 \text { classroom } \\
\text { observations } \\
\text { for the six } \\
\text { focus } \\
\text { participants }\end{array}$} & $\begin{array}{l}\text { Lesson plans, } \\
\text { reflection, samples } \\
\text { of students' work, } \\
\text { informal discussion }\end{array}$ \\
\hline & & $\begin{array}{l}\text { 4th Interview } \\
\text { (July 08): After } \\
\text { the first year of } \\
\text { teaching (July 08) }\end{array}$ & $\begin{array}{l}\text { 3rd } \\
\text { discussion } \\
\text { (June 08) }\end{array}$ & & $\begin{array}{l}\text { Lesson plans, } \\
\text { reflection, samples } \\
\text { of students' work, } \\
\text { informal discussion }\end{array}$ \\
\hline
\end{tabular}


We presented the detailed information about the participants, research methods and major findings of the first year study in Gao, Choy, Wong and Wu (2009). We collected the survey data from a cohort of 118 participants at four data collection points to gain a big picture about their changes in perception and self-reported use of ICT (Choy, Wong \& Gao, 2009). Concurrently, we used qualitative research methods to get indepth insights into how participants constructed their understanding about using information technology for classroom teaching and learning from their own practice. We purposefully selected ten focus participants from among those who volunteered. As we wanted participants across a wide range of comfort level for using ICT for classroom teaching and learning, we selected the ten based on their self-reported comfort levels of using ICT for classroom teaching indicated in the first survey, as well as their age, gender and subject majors. At the end of the selection process, we had five males and five females and their ages ranged from late 20s to mid 40s. Six of them majored in Chinese Language, and four of them majored in General Education (Teaching of English, Mathematics and Science) for primary schools.

We engaged in an iterative process of qualitative data collection and analysis. Within two years, we conducted four one-on-one interviews for each focus participant. Each interview lasted around 30-50 minutes, and was verbatim transcribed. Additionally, we conducted three focus group discussions to involve all the focus participants. We asked the participants to share their beliefs about teaching, perceptions of using ICT for classroom teaching and learning, decision making for using/not using ICT, how/why/when they used ICT, challenges of using ICT, and what they learned from such experiences. In total, we conducted and videotaped 13 one-hour lesson observations during the ten-week student teaching for seven participants who felt comfortable to be video recorded. We obtained permission from all the schools before all the lesson observations.

During the first year of teaching, we continued video recording an additional 56 classroom observations for six of these seven participants. These included lesson observations in a particular unit of study across grade levels for the five Chinese Language participants, across content areas for one General Education participant, and unscheduled observations on a monthly basis for all six, to get an authentic picture of their regular teaching. For every observation, we focused on how and why they used ICT in their teaching. Immediately after each observation, we held a brief, postobservation discussion with the focus participant to probe his/her reflections. We wrote field notes for each observation and collected hard copies of their lesson plans and samples of their students' work as artifacts. The remaining participants, who did not want their lessons to be observed, continued to be involved in all the other data collection events like the interviews and group discussions.

We used the constant comparative method (Strauss, 1987), triangulating investigators and data (Lincoln \& Guba, 1985) to analyse and interpret the data of the first year of the study. We followed the coding steps outlined by Strauss (1987): coding, identifying emerging themes while writing memos. We verified the interview data with the observation notes, lesson videos and the analysis notes. In order to establish confidence in the trustworthiness of the findings (Patton, 1990), we conducted ongoing peer review of the data analysis among the research team members. At the final phase of the data analysis, we created a profile of each participant and conducted "member check" (Lincoln \& Guba, 1985) for the interview transcripts and the profile of the participants. 
For the purpose of this paper, only participants who showed leadership potential in an effort to promote the use of ICT in their classrooms and beyond were considered. Among the ten focus participants, three stood out from the rest They had begun developing their leadership potential during their ten-week of student teaching. During their first year of teaching, they continued to develop their leadership potential for technology integration by teaching with technology, leading their colleagues in school-wide technology initiatives, and supporting other beginning teachers. The development of their leadership potential will be discussed in the results section.

\section{Results}

The purpose of this paper is to investigate three beginning teachers' beliefs about technology integration - whether they were able to develop, sustain and apply their leadership potential for technology integration in Singapore schools during their student teaching and first year of teaching. The results reported focused on the qualitative findings of this two-year mixed method study, and in particular, the developmental process of three beginning teachers, Max, Henry and Harold (pseudonyms), over the period of two years in their respective schools.

By coincidence all three selected focus participants were male Singaporeans, majoring in Chinese Language and Literature (Primary). Henry and Harold belonged to the Gen $Y$ population as they were in their late 20s and Max was in his early 30s. After obtaining their Bachelor degrees, all of them had worked in the private sector for different lengths of time, ranging from 3 months to 8 years. They shifted their career to the education sector, citing the reason that they wanted to make a difference in someone's life. For example, Max shared that: "Although teaching is something that I wanted to do since I graduated ... Some people might find it very cliché to say that it is a calling ... I think that's where I'm coming from and I think teaching will actually satisfy that need to have meaningfulness [in life] ...." (Max, First Interview). However, they differed in the entry comfort level for using ICT for student learning. Max selfreported to have a medium comfort level for using ICT for classroom teaching and learning, while Henry and Harold reported a high comfort level. All of them participated in the four individual interviews and the first two group discussions in the first year of study. Due to personal commitments, Henry and Harold did not attend the third group discussion. We had two lesson observations with both Henry and Max and one with Harold during their student teaching. For the first year of teaching, we had six lesson observations with Henry, five with Harold, and eight with Max. Both the interviews and observations showed that they demonstrated their capability to develop and apply their leadership potential for technology integration within the two years of the study. Table 2 summarises the major themes and subthemes that emerged from the coding of the interviews, discussion and observation data in the three stages of their learning process.

The three beginning teachers stood out from the rest because they were able to develop a change agenda and sustained a constructivist orientation during the ICT course. Throughout the ten weeks of students practice teaching, they tried out different approaches to effectively use ICT to enhance student learning and extended their influence beyond their classrooms. During their first year of teaching, they took the initiative to extend their students' learning beyond the classroom, and shared resources and practices within their schools. They extended their influence beyond their classrooms by leading school-wide technology initiatives and supporting their university peers in technology integration. 
Table 2: Process and themes

\begin{tabular}{|c|c|c|}
\hline Learning process & Themes & Sub-themes \\
\hline $\begin{array}{l}\text { Learning from the } \\
\text { ICT course }\end{array}$ & Beliefs & $\begin{array}{l}\text { - Bringing prior beliefs into teacher education program } \\
\text { - Developing constructivist orientation } \\
\text { - Expressing a passion to translate their beliefs into student } \\
\text { teaching }\end{array}$ \\
\hline $\begin{array}{l}\text { Learning from } \\
\text { student teaching }\end{array}$ & Practices & $\begin{array}{l}\text { - Trying out different technology applications } \\
\text { - } \text { Discovering their technology savvy strengths } \\
\text { Influencing their cooperating teachers by modelling and } \\
\text { sharing }\end{array}$ \\
\hline $\begin{array}{l}\text { Learning from first } \\
\text { year teaching }\end{array}$ & $\begin{array}{l}\text { Performing } \\
\text { leadership } \\
\text { potential }\end{array}$ & $\begin{array}{l}\text { - Building on their 'tech-savvy' strengths } \\
\text { - Taking initiative and risks } \\
\text { - Extending learning beyond the classroom } \\
\text { - Making an impact on student learning } \\
\text { - Sharing resources and practices } \\
\text { - Leading school-wide technology initiatives } \\
\text { - Supporting their university peers }\end{array}$ \\
\hline
\end{tabular}

In the following sections, we present the three participants' process of developing leadership potential for technology integration according to the sequence of their learning and teaching experiences.

\section{Developing constructivist orientation during their university courses}

The three participants' general beliefs on teaching, and their perceptions on using ICT, were well established before enrolling in their initial teacher preparation program. Their beliefs were partially influenced by a teaching stint that they had before their pre-service teacher education.

After taking various courses, including the ICT course, in the pre-service teacher education program, Max, Henry and Harold seemed to be able to draw a meaningful connections among the content, student-centred teaching approaches and the effective use of ICT in the classroom. This was reflected in Henry's words:

I've learnt that ICT actually shifts the paradigm from teaching to learning and it emphasises a lot on students' learning. When actually incorporating ICT skills in teaching, it is more student-centred as compared to the conventional classroom ... The use of ICT can trigger off students' thirst for knowledge. They can actually get more participative in student-centred learning. (Henry, First Interview).

They began to develop and sustain their constructivist orientation by emphasising the importance of "students learn, rather than teachers teach" (Henry, First Interview). Similarly, Max acknowledged the positive impact of the ICT course: "It actually shows us how students construct their knowledge and how they actually learn at their individual pace" (Max, Second Interview). He was determined to try out what he had learned in the teacher education program during his student teaching:

I want to try it out to apply what I have learned in the university. Most of time, we tend not to take risks [in trying new things] because we are too conscious of being observed (and graded) by our professors and by our CTs (cooperating teachers). But now I think I should be more open minded in trying different technologies ... The fact is, if we don't try, we will never know what are the issues that we may encounter. (Max, Second Interview) 
It seems that the participants were eager to change the established practice of using ICT. They were willing to take risks to try out new ways of using ICT for classroom teaching and learning.

\section{Developing leadership potential for technology integration during student teaching}

Indeed, Max, Henry and Harold attempted to explore different technology applications to enhance their student learning during the ten-week student teaching. For example, during one observation, Max implemented a WebQuest activity that was developed by him and his classmate for the ICT course at the university. He arranged his students to work in collaborative groups to solve a real life problem. In another observed lesson, after showing his students an online report and a Flash animation on plagiarism, Max arranged his students in groups to discuss the issue of plagiarism from three different perspectives (the party whose copyright was violated, the person who violated it, and a third person). He ended the lesson by having his students present their findings.

Similarly, Henry integrated ICT for a student-centred learning activity for one observed lesson by adopting the learning stations approach for a revision lesson for his Primary Two pupils. At one station, he set up two desktops to use Hot Potatoes, an online self-assessment tool, to have his students receive instant feedback. Henry was excited to see that the students were "very engaged throughout the entire activity in class ... it benefitted them a lot by boost[ing] their confidence" (Henry, Postobservation conference).

Harold revealed during the second interview that he frequently created hands-on learning opportunities for his students in the computer laboratory for self-regulated learning. During one observed lesson conducted in the computer laboratory, Harold allowed his high-ability Primary 3 pupils to work individually on the website designed by the Ministry of Education and to play games as an introduction to the unit of study. He became more flexible by allowing the students who had completed the assignment ahead of the others to explore other learning activities on the website.

The positive experiences empowered Max, Henry and Harold to think about making an impact in technology integration as pre-service teachers. Max commented: "I think that Rule No. 1 is to be a role model. I think that you got to be able to use technology. I think the next step is to share how you actually conduct the lesson within the department" (Max, Second Interview). Similarly, Henry found encouragement when he received positive feedback from his cooperating teachers and other teachers in the school. He was approached by other teachers for the lesson plans and the Hot Potatoes resources he created for his revision lesson.

Harold thought about his influence from an ideological perspective after his student teaching:

I am more interested to convince my peers, my colleagues to use ICT in classroom because I feel that if the more teachers use ICT, I think this environment thing (student-centred learning) will emerge, and gradually you will see more students, more teachers are more willing to use it. If more teachers are willing to use it I think the management will be more willing to accept ... (Henry, Second Interview) 
After translating their constructivist beliefs into practice, they began to draw a connection between beliefs and practices. Based on the success of implementing teacher centred approaches in their own classrooms, they extended their influence beyond their classrooms to inspire their cooperating teachers to integrate technology in their classrooms. They developed a passion to make a larger impact after becoming a full-fledged teacher.

\section{Impacting student learning during their first year teaching}

The transition from student teacher to full-fledged teacher provided Max, Henry and Harold both challenges and opportunities to execute their influence both within and beyond their classrooms. On one hand, they lacked the time to plan technology-based lessons because their teaching load was twice of what they had during student teaching. On the other hand, they had a sense of autonomy and individual identity. Henry illustrated his change of individual identity in the following way:

During my student teaching, I actually did things to cater to my Cooperating

Teachers. But as a teacher now, I would do things in my own way. I would actually evaluate the students (to see) whether my methods work. Actually, it is more of being myself now rather than catering to other people. (Henry, Third Interview)

Max, Henry and Harold were committed to their sustainable efforts in exploring the effective use of ICT to enhance their students' learning. For example, in addition to using PowerPoint slides regularly as a concept mapping tool to help students generate ideas, Max took the students to the computer laboratory regularly to expose them to online modes of communication, such as MSN and Google Chat. He created a learning environment of collaboration among students and assigned them to co-write Chinese essays in groups in the computer laboratory, encouraging them to continue to work on it over the weekend. He saw three benefits: firstly, students did MSN after class and "it shows them that you can actually carry on the learning after class". Secondly, their home access is faster than the school's. Thirdly, "... for them to type in Chinese, it is something that they are not quite used to" (Max, Third Interview).

During his first year of teaching, Henry decided to expand the online story-reading program that he developed during student teaching for his Primary Four students. His reasons were: "Everything has been established ... the most important part is that there are abundant resources. Students have the ability to think out of the box ... they don't want books ... but when they read in the lab, it is new to them. They are given the freedom to decide whether to continue to read" (Henry, Third Interview). He took his fourth graders to the computer laboratory on a weekly basis, to allow them to choose stories for self-paced learning from his co-developed online reading program for his school. Henry used different technology applications for different purposes, such as PowerPoint presentations for delivering the content, Inspiration software to generate concept maps, Hot Potatoes to conduct self assessment, and blogging to encourage students to provide feedback. He used responsive approaches to cater to the needs of students in his classes:

For my high ability class, most of the time I will let them follow a certain framework, and allow them to just do it themselves unless it is new to them. For my middle ability class, I would step in to guide them along, because once they are lost, they will be forever lost ... (Henry, Third Interview) 
Harold took advantage of the easy access to ICT and using a new curriculum to create enhanced learning opportunities for Primary Two (P2) students. He became flexible in pedagogically using a variety of ICT tools to allow his students to take responsibility for their own learning. As a result of his innovative use of ICT for enhancing student learning, his students' learning outcomes increased significantly. He observed that:

\begin{abstract}
My P2 students used to fail the exam ... they could hardly read or write a proper paragraph in the past. The average mark used to be No. 6 (ranked 6th out of nine classes). But now after 6 months, they can write. All of them have hit the target and gone beyond expectations. And one of our students scored the highest among all the students in the grade for Chinese. Now the average mark for my P2 class is No. 2 ... (Harold, Third Interview)
\end{abstract}

Harold achieved his intended teaching objectives by commenting that: "Some parents told my Head of Department (HOD) that their children used to speak English at home. But now they are using Chinese instead ... So I think I have achieved my goal to stimulate an interest in Chinese, although it is just the beginning." (Harold, Fourth Interview).

In brief, Max, Henry and Harold used ICT not only for covering the curriculum but also to extend student learning beyond the four walls of a classroom and to better prepare them for future success.

\title{
Developing leadership potential for technology integration during first year teaching
}

Max, Henry and Harold demonstrated different levels of leadership potential for technology integration, such as sharing, supporting and leading others in technology integration. They developed critical agency - questioning the accepted practice. For example, Max noticed that the pressure to cover the curriculum and prepare the students for examinations posed a major challenge for teachers incorporating ICT for classroom teaching and learning:

I think it is still quite far [from integrating ICT] ... because whenever we talk about examinations, we tend to think firstly what will be assessed, and then what to teach secondly. We should do it the other way around, where we think about what we want the students to learn first, and then look at issues related to examinations. (Max, Third Interview)

Henry and Harold were recognised for their 'tech-savvy' strengths, and were appointed members of the ICT committee during their first year of teaching in their respective schools. They went the extra mile to support and lead their colleagues into technology integration. In addition to expanding his online story-reading program for P4 as mentioned above, Henry initiated another online reading program for P3 to P6 students. He thought, "there is no harm for giving it a try" (Henry, Third Interview). He worked collaboratively with his colleagues to capitalise on one another's strengths:

We are strong in different areas ... for example my area may be webpage design and my friends are strong in coming up with activities and sourcing for stories ... So it's like we are actually putting our strengths together to achieve the goal. (Henry, Fourth Interview)

Henry perceived his role in the two committees of online story-reading program as "more of a planning ... I spend more time on planning rather than teaching them 
(teachers) one by one" (Henry, Third Interview). He viewed himself as a "sharing person": "I uploaded a lot of my ICT stuff. I think that really alleviates other teachers' workload ... I would say for this half year it is more of sharing worksheets on a school basis". He benefited from the sharing culture in his department: "We have formed a Yahoo group for the Chinese Language department. Everything is shared online" (Henry, Third Interview).

Like Henry, Harold was also willing to share what he had done for enhancing student learning within the school. He commented: "When I share something with them, it's important to let them see it as an opportunity rather than as a challenge" (Harold, Fourth Interview). He was in charge of formulating the school based curriculum, including worksheets, PowerPoint presentations and lesson plans. In addition, "As the ICT representative for the Chinese Department, I have to support the 20 plus teachers in my Chinese Language department" (Harold, Fourth Interview). Harold received the "Best Beginning Teacher Award" in his school after six months of service in the school, partly because of his leadership in several school initiatives, one being the Technology Initiative. He had developed his unique identity of a team leader as a first-year teacher. He commented:

I am the type of person who will jump in and interfere when I see something going wrong. I am strong in ICT and they [my colleagues] don't have a very good understanding of it. So they may think that I am able to help them ... I think I am more a team leader than a team player. In a few committees, I am either a team leader or an assistant chair. (Harold, Fourth Interview)

In addition, Harold was involved in supporting his NIE peers in other schools providing emotional support and sharing resources by establishing their own Yahoo learning community:

They are my group mates in NIE from the same class. We are very close to each other. So we can work well together. For example, I may tell them "these are my teaching materials for the month". I will use our own Yahoo group to upload the materials so that they can download ... When I share my practice, I know that my approach may not be the best, so when we share, we look for better solutions and we are advise each other. (Harold, Fourth Interview)

In this two-year study, our interviews and lesson observations were able to show that the selected three focus participants held positive beliefs about integrating technology to enhance their students' learning. Some of these positive beliefs had begun to develop even before their pre-service teacher education program. When they became pre-service teachers, they learned from their coursework about different studentcentred learning pedagogies and ways to integrate ICT into their classrooms more effectively. Towards the end of their program, they began to apply and integrate ICT into their ten-week student teaching. They also gradually started to develop their leadership potential during their student teaching. After they graduated from the preservice teacher education, they were able to sustain their positive beliefs and continued to develop their leadership potential for technology integration in schools. On different occasions, all three of them showed how they impacted their students' learning. They were also able to hone their leadership potential for technology integration through sharing with their colleagues and peers. 


\section{Discussion and implications}

This paper presented the developmental process of three beginning teachers' leadership potential for technology integration. This finding differs from the results of previous research which found that most pre-service and beginning teachers do not translate their high ICT skills and comfort level for using ICT into high levels of technology integration in daily classroom instruction (Andersson, 2006; Russell et al., 2003; Wright \& Wilson, 2005). Evidently, in this study, the three participants were eager to change the established practice of using ICT. They were willing to take risks to try out new ways of using ICT for classroom teaching and learning. Their beliefs of technology integration helped them to translate their high ICT skills and comfort level for using ICT into high levels of technology integration in daily classroom practices. After developing responsive teaching approaches to meet the needs of their students, they became flexible in using various technologies to enhance their students' learning. They designed learning environments that changed the relationship between teacher, student and technology tools and allowed their students to take responsibility for their own learning.

This finding also challenged the conventional wisdom that beginning teachers tended to be concerned with matters pertaining to survival at the initial stage of professional development, such as concerns about self, tasks, and students (Fuller, 1969). To a certain extent, like most beginning teachers, the three participants shared these common concerns. However, they tended to focus their attention on "high ideals, hope, realism, and compassion for others" (Ayers, 2001; p.9). On top of learning from university courses, they learned most of what they needed to know as a teacher leader from "the process of performing their work" (Lieberman \& Miller, 2004). They started by taking small steps that were within their control, shifting their attention to placing learning instead of teaching, first. They learnt to be flexible, and this helped them to develop responsive teaching approaches which allowed their students to use ICT for learning enhancement. Their own practice convinced them that they can make a difference in their students' learning by using ICT effectively.

As the participants explored constructive teaching approaches while using ICT during their first year teaching, they discovered their own 'tech savvy' strengths. Their strengths provided them the opportunity to excel in a niche area in their schools. They were eager to expand their influence to lead others to develop the same zeal "to improve teaching and learning practices with the aim of increased student learning and achievement" (Lieberman \& Miller, 2004). They created their status as potential teacher leaders through their own performance of demonstrating the characteristics of teacher leaders as discussed in the literature review. Such a finding is aligned with the result that beginning teachers can learn to teach with ICT and learn to lead in technology integration at the beginning stage of teacher development (Gao, 2005). In sum, the development of leadership is not a result of seniority but an observable, learnable set of practices (Kouzes \& Posner, 1995).

This study suggested that the development of beginning teachers' leadership potential is not an event, but a process in which they discover and build on their 'tech-savvy' strengths, and negotiate their agency and power in the multiple social contexts. We recommend that teacher education programm look into creating a systematic structure to prepare pre-service teachers as teacher leaders. Teacher education programs should not only prepare their pre-service teachers in the skills, knowledge and attitude about using ICT in classroom teaching and learning, but also in the knowledge of change, 
such as taking initiative and risks, engaging in inquiry and refection, and supporting others to do so. In that way, they can sustain and continue to develop their leadership potential as they progress from being a pre-service teacher to beginning teacher.

Further research can explore the relationship between pre-service teachers' technology competency with performance of leadership potential, and how pre-service teachers can be empowered to capitalise on their strengths of technology integration. Future studies can also investigate the institutional contexts in the placement schools, such as, the kinds of the relationship between pre-service teachers and cooperating teachers that can empower pre-service teachers to become change agents. Collaborations between teacher education programs and placement schools is another potential area for investigation. This study focuses on the perspective from the beginning teachers. Other studies can investigate the perspective from the others, such as school administrators, other teachers in the school, and even the students of teacher leaders.

There are some limitations in this study. The number of focus participants was relatively small as they were being invited to participate on a voluntary basis. It could have affected some of the participants' thoughts and reports. In addition, the three focus participants happened to have the same major - Chinese Language and Literature and same gender - male beginning teachers. It may lead to the question whether developing teacher leadership potential is subject specific or/and gender specific. Hence, further quantitative and qualitative longitudinal studies can be conducted in other content areas with a mix of male and female beginning teachers to see whether similar results are obtained.

\section{Conclusion}

This paper reported one major finding from a two-year study which examined the development of leadership potential for technology integration from the perspective of three beginning teachers. It detailed how three beginning teachers integrated ICT in their student teaching and first year of teaching. It also explored how they supported and led other colleagues and peers to integrate ICT effectively in their classrooms so as to enhance their students' learning. This finding suggested that beginning teachers were able to learn to teach with ICT and lead in technology integration simultaneously. Thus, learning to teach with ICT holds the potential of transforming teaching and learning in schools with beginning teachers acting as the change agents (Gao, 2005). Many teacher education institutions now see the early preparation of teacher leaders as part of their mission. The findings reported in this paper suggested that it is possible for teacher education programs to prepare pre-service teachers to be teacher leaders by capitalising on pre-service teachers' strengths. It may start with preparing beginning teachers to become teacher leaders for technology integration. This study also shed new insights on teacher induction. Larger and longitudinal-type studies are needed to systematically explore how to prepare future teachers and leaders.

\section{Acknowledgment}

The work represented in this paper was funded by two Learning Sciences Laboratory research grants, number LSL0307GP and LSL0407GP at the National Institute of Education, Singapore. Special thanks to the ten beginning teachers who participated in the qualitative portion of the research for their contributions. 


\section{References}

Andersson, S. B. (2006). Newly qualified teachers' learning related to their use of information and communication technology: A Swedish perspective. British Journal of Educational Technology, 37(5), 665-682.

Andrew, M. D. \& Schwab, R. L. (1993). On outcome assessment of graduates of eleven teacher education programs. Paper presented at the annual meeting of America Educational Research Association. Atlanta, GA., 12-16 April. [verified 28 Jun 2010] http: / / www.eric.ed.gov/ PDFS / ED360272.pdf

Ayers, W. (2001). To teach: The journey of a teacher. NY: Teachers College Press.

Bird, T. \& Rosaen, C. L. (2005). Providing authentic contexts for learning information technology in teacher preparation. Journal of Technology and Teacher Education, 13(2), 211-221.

Brown, D. \& Warschauer, M. (2006). From the university to the elementary classroom: Students' experiences in learning to integrate technology in instruction. Journal of Technology and Teacher Education, 14(3), 599-621.

Choy, D., Wong, A. F. L. \& Gao, P. (2009). Student teachers' intentions and actions on integrating technology into their classrooms during student teaching: A Singapore study. Journal of Research on Technology in Education, 42(2), 173-193.

Clausen, J. M. (2007). Beginning teachers' technology use: First-year teacher development and the institutional context's affect on new teachers' instructional technology use with students. Journal of Research on Technology in Education, 35(3), 245-261.

Cochran-Smith, M. (1991). Learning to teach against the grain. Harvard Educational Review, 51(3), 279-310.

Darling-Hammond, L. (2000). Teacher quality and student achievement: A review of state policy evidence. Educational Policy Analysis Archives, 8(1). [viewed 23 June 2010]. http: / / epaa.asu.edu/ojs/article/viewFile/392/515

Denzin, H. (1984). The research act. Englewood Cliffs, NJ: Prentice-Hall.

Donnison, S. (2005). Learning on hold: South-east Queensland preservice teachers and their understanding of lifelong learning. Paper presented at the 35th Annual Conference of the Standing Conference on University Teaching and Research in the Education of Adults, Brighton, England, 5-7 July. http:/ / en.scientificcommons.org/33244650 [viewed 1 Jun 2010, abstract only]

Donnison, S. (2007). Digital generation pre-service teachers as change agents: A paradox. Australasian Journal of Teacher Education, 32(4), 1-12. http: / / ajte.education.ecu.edu.au/issues/PDF/324/Donnison.pdf

Donnison, S. (2009). Discourses in conflict: The relationship between Gen Y pre-service teachers, digital technologies and lifelong learning. Australasian Journal of Educational Technology, 25(3), 336-350. http:/ / www.ascilite.org.au/ ajet/ajet25/donnison.html

Fuller, F. F. (1969). Concerns of teachers: A developmental conceptualization. American Educational Research Journal, 6(2), 207-289.

Gao, P. (2005). Learning to teach with information technology: Preservice teachers' perspectives and experiences across their three-semester preparation. Dissertation Abstracts International, 66(10), 3550. (UMI No. 3194016). 
Gao, P., Choy, D., Wong, A. F. L. \& Wu, J. (2009). Developing better understanding of technology-based pedagogy. Australasian Journal of Educational Technology, 25(5), 714-730. http: / / www.ascilite.org.au/ajet/ajet25/gao.html

Goodlad, J. (1990). Teachers for our nation's schools. San Francisco, CA: Jossey Bass.

Goos, M. (2005). A sociocultural analysis of the development of pre-service and beginning teachers' pedagogical identities as users of technology. Journal of Mathematics Teacher Education, 8(1), 35-59.

Howey, K. R. (1988). Why teacher leadership? Journal of Teacher Education, 39(1), 28-31.

Johnson, M. J., Schwab, R. \& Foa, L. (1999). Technology as a change agent for the teaching process. Theory Into Practice, 38(1), 24-30.

Katzenmeyer, M. \& Moller, G. (2001). Awakening the sleeping giant: Helping teachers develop as leaders. Thousand Oaks, CA: Corwin Press.

Kay, R. H. \& Knaack, L. (2005). A case for ubiquitous, integrated computing in teacher education. Technology, Pedagogy and Education, 14(3), 391-412.

Kouzes, J. M. \& Posner, B. Z. (1995). The leadership challenge. San Francisco, CA: Jossey-Bass.

Lieberman, A. \& Miller, L. (2004). Teacher leadership. San Francisco, CA: Jossey-Bass.

Lincoln, Y. S. \& Guba, E. G. (1985). Naturalistic inquiry. London: Sage.

McGee, P. (2000). Persistence and motivation: A new teacher's path to technology infusion. Computers in the Schools, 16(3/4), 197-212.

Patton, M. Q. (1990). Qualitative evaluation and research methods (2nd ed.). Thousand Oaks, CA: Sage.

Paul, P. (2001). Echo boomerang. American Demographics, 23(6), 44-49.

Pierson, M. E. \& Cozart, A. (2005). Case studies of future teachers: Learning to teach with technology. Journal of Computing in Teacher Education, 21(2), 59-63.

Russell, M., Bebell, D., O’Dwyer, L. \& O'Connor, K. (2003). Examining teacher technology use: Implications for preservice and inservice teacher preparation. Journal of Teacher Education, 54(4), 297-310.

Shepherdson, N. (2000). Life's a beach 101. American Demographics, 22(5), 56-64.

Strauss, A. (1987). Qualitative analysis for social scientists. Cambridge, England: Cambridge University Press.

Thompson, A. D., Schmidt, D. A. \& Davis, N. E. (2003). Technology collaboratives for simultaneous renewal in teacher education. Educational Technology Research and Development, 51(1), 73-89.

Wasley, P. (1991). Teachers as leaders: The rhetoric of reform and the realities of practice. New York: Teachers College Press.

Wright, V. H. \& Wilson, E. K. (2005). From preservice to inservice teaching: A study of technology integration. Journal of Computing in Teacher Education, 22(2), 49-55. 
York-Barr, J. \& Duke, K. (2004). What do we know about teacher leadership? Findings from two decades of scholarship. Review of Educational Research, 74(3), 255-316.

Dr Ping Gao

Assistant Professor, Learning Sciences and Technologies Academic Group

National Institute of Education, Nanyang Technological University

1 Nanyang Walk, Singapore 637616. Email: ping.gao@nie.edu.sg

Dr Angela F. L. Wong

Associate Professor, Learning Sciences and Technologies Academic Group

National Institute of Education, Nanyang Technological University

1 Nanyang Walk, Singapore 637616. Email: angela.wong@nie.edu.sg

Dr Doris Choy

Assistant Professor, Learning Sciences and Technologies Academic Group

National Institute of Education, Nanyang Technological University

1 Nanyang Walk, Singapore 637616. Email: doris.choy@nie.edu.sg

Ms Jing Wu

Research Associate, Centre for Research in Pedagogy and Practice

National Institute of Education, Nanyang Technological University

1 Nanyang Walk, Singapore 637616. Email: jing.wu@nie.edu.sg 